\title{
Una nueva puzolana para materiales cementicios de elevadas prestaciones
}

\author{
A new pozzolan for high performance \\ cementitious materials
}

\author{
RUBY M. de GUTIÉRREZ, S. DELVASTO \\ Escuela de Ingeniería de Materiales. Univ. del Valle
}

COLOMBIA

Fecha de recepción: 1-XII-99

R. TALERO MORALES

Fecha de aceptación: 4-IV-00

Instituto de Ciencias de la Construcción Eduardo Torroja (CSIC)

ESPAÑA

\section{RESUMEN}

Este artículo reporta los resultados de las propiedades fisicas y quimicas de un producto denominado metacaolín, MK; que fue preparado a partir del tratamiento térmico controlado de una caolinita de alta pureza. Se discuten las propiedades de morteros de cemento adicionados con MK en porcentajes hasta del 50\%. Las propiedades investigadas corresponden a la resistencia a la compresión, la distribución del tamaño de poros, la resistencia a la penetración del agua y los iones cloruro y el comportamiento a la corrosión de barras de acero de refuerzo embebidas en este material. Se concluye que para alcanzar un hormigón de alta resistencia se requiere un porcentaje de adición del orden del $20 \%$, pero que mayores porcentajes permiten un incremento notable en la durabilidad del material, manteniendo una resistencia en orden similar a la de la mezcla de control. En general, los resultados obtenidos en el estudio indican que el MK corresponde a un material de excelente actividad puzolánica que puede ser utilizado para producir hormigones de elevadas prestaciones, particularmente, en ambientes marinos y sales de deshielo. Se atribuye este efecto a que da origen a productos de muy baja permeabilidad y a su excelente capacidad de enlace frente al ión cloruro para formar la sal de Friedel, tal como se demuestra mediante técnicas de DRX.

\section{SUMMARY}

This paper presents results on the physical and chemical properties of metakaolinite, MK which is prepared by dehydroxylation of high quality kaolinite. The properties of portland cement mortars blended with MK additions up to $50 \%$ are investigated. These properties are compressive strength, pore size distribution, resistance to the penetration of water and chloride ions and corrosion performance of steels embedded in the mortar. The optimum replacement of ordinary portland cement (OPC) with MK to obtain high strength concrete is about $20 \%$, but it is possible to use a higher percent in order to achieve the best durability properties and strength similar to the control mixture. There is a significant decrease in average pore size with an increase in MK replacement. Metakaolinite is able to bind chloride ions to produce Friedel's salt (SF), which can be considered as the main cause of the lower chloride penetration in portland cement mortars blended with $M K$ addition. This chemical binding capacity was proved by $X R D$. In general, the test results indicate that the MK is a highly pozzolanic material and can be used as a supplementary cementing material in order to produce a high-performance concrete especially for use in aggressive environments. Such as, thawing salts and dew of the sea. 


\section{INTRODUCCIÓN}

La Norma ASTM C618, define una puzolana como un material síliceo o silico-aluminoso que, por sí mismo, posee poco o ningún valor cementicio pero finamente molido y en presencia de humedad, reacciona químicamente con el hidróxido cálcico, $\mathrm{Ca}\left(\mathrm{OH}_{2}\right)$, a temperatura ordinaria y forma compuestos de propiedades cementantes.

Por esta razón, el reemplazo parcial de cementos portland ordinarios, OPC, por material puzolánico, natural o artificial, puede ser ventajoso, debido a que estos materiales incrementan una o más propiedades, tales como la resistencia a la compresión y/o las propiedades de durabilidad. Aquí, la puzolana reacciona con el hidróxido cálcico generado en la hidratación del cemento y da lugar a compuestos cementicios. Debido a esta reacción, se desarrolla en el material una estructura de poro fino y la permeabilidad es reducida (1).

El metacaolín, MK, es una puzolana tipo aluminosilicato altamente reactiva que se produce por la calcinación de caolinita pura a una temperatura específica. $\mathrm{La}$ reactividad puzolánica del metacaolín está determinada por las propiedades mineralógicas de la arcilla de origen, así como por las condiciones del proceso de calcinación (2) (3) (4). El tratamiento térmico de la caolinita a temperaturas entre $\operatorname{los} 300^{\circ} \mathrm{C}$ y $1200^{\circ} \mathrm{C}$ da lugar a reordenamientos atómicos que inducen a la generación de nuevas fases, algunas cristalinas y otras amorfas. Mediante estudios de NMR algunos investigadores (5) han detectado la presencia de aluminio tetra y pentacoordinado en el metacaolín.

La bibliografia publicada sobre las propiedades del metacaolín y sus ventajas de utilización en hormigones, ha aumentado notablemente desde 1983 a la fecha, de tal modo que en algunos países, en los últimos años, se está explotando a nivel comercial (6) (7). En los diferentes estudios se indica su contribución en las resistencias mecánicas y en la reducción de la permeabilidad de los materiales cementicios, con resultados comparables al humo de sílice y una ventaja notable, su color blanco, que le permite ser usado en aplicaciones especiales (8) (9) (10). Igualmente se ha estudiado su efecto frente a la reacción álcali-sílice, a los medios sulfatados y a otros ambientes agresivos (11) (12) (13).

El objetivo de esta investigación fue evaluar la utilización de MK como una adición al cemento y su potencial aplicación en la producción de hormigones de elevadas prestaciones ante el ataque de los cloruros. Este articulo presenta los resultados de las propiedades físicas, químicas, mecánicas y de durabilidad de morteros de cementos portland adicionados con MK en proporción hasta del $50 \%$.

\section{INTRODUCTION}

A pozzolan, in ASTM C618, is defined as a siliceous or siliceous and aluminous material which, by itself has little or no cementitious value but which in finely divided form and in presence of moisture reacts chemically with calcium hydroxide at ordinary temperature to form compounds with cementitious properties.

For this reason, the partial replacement of ordinary portland cements, OPC, with pozzolanic material, natural or by-product can be advantageous occasionally, because these materials increase one or more properties such as the compressive strength and/ or durability properties. Here, the pozzolan reacts with the calcium hydroxide that is produced by the cement hydration to produce cementitious compounds. Because of the reaction, a finer pore structure is developed and the permeability is reduced (1).

Metakaolinite, $M K$, is a reactive aluminosilicate pozzolan that is produced by calcining pure kaolinite at a specified temperature. The pozzolanic reactivity of the $M K$ is determined by the mineralogical properties of the raw kaolinite and the calcination process (2) (3) (4). Thermal treatment of kaolinite between $300{ }^{\circ} \mathrm{C}$ and $1200{ }^{\circ} \mathrm{C}$ produces atomic rearrangements and induces the formation of new phases, crystalline and amorphous. The use of NMR spectroscopy has allowed the detection of the presence of tetra and pentacoordinated aluminum in metakaolinite (5).

The published literature on MK blended cements has grown rapidly since 1983 and this addition are now being utilized commercially in several countries (6) (7) The results of the different studies have indicated that $M K$ is a high quality admixture that increases the strength development and reduces the permeability. $M K$ yields performance comparable to silica fume (8) (9). Because of its white color, MK does not darken concrete as silica fume does. This makes it ideal for some special applications (10). It is reported that $M K$ also increases resistance to alkali-silica reaction, sulphates and other aggressive environments (11) (12) (13).

The objective of this research was to provide information on the utilization of $M K$ as a supplementary cementing material in order to produce high performance concrete against chlorides attack. This paper presents data on the physical, chemical, mechanical and durability properties of portland cement mortars blended with MK up to 50\% of incorporation (weight by weight basis). 


\section{PROCEDIMIENTO EXPERIMENTAL}

Los materiales utilizados fueron cementos portland ordinarios (OPC) y una puzolana tipo aluminosilicato. Las propiedades físicas y químicas de estos materiales se presentan en la Tabla 1. El peso específico (S.G.) se determinó en el frasco de Le Chatelier y la superficie específica (B.F.) fue medida haciendo uso del permeabilímetro Blaine. El MK fue obtenido por tratamiento térmico de la caolinita a $750^{\circ} \mathrm{C}(14)$. En este proceso se produce la eliminación de las dos moléculas de agua combinadas en la fórmula molecular de la arcilla original.

\section{EXPERIMENTAL PROCEDURE}

The materials used in this research were ordinary portland cements $(O P C)$ and an aluminosilicate pozzolan. The chemical and physical properties of these materials are presented in Table 1. The specific gravity (S.G.) and the Blaine specific surface (B. F.) were determined by the method specified in ASTM standard. The $M K$ was obtained by dehydroxylation of kaolinite in a furnace at $750{ }^{\circ} \mathrm{C}(14)$. This thermal treatment resulted in the collapse of the crystalline structure of the raw material. Dehydroxylation of kaolinite is produced by elimination of two molecules of water combined in each mole of the original clay.

$$
\mathrm{Al}_{2}(\mathrm{OH})_{4} \mathrm{Si}_{2} \mathrm{O}_{5} \longrightarrow \mathrm{Al}_{2} \mathrm{O}_{3} 2 \mathrm{SiO}_{2}+2 \mathrm{H}_{2} \mathrm{O}
$$

TABLA 1 / TABLE 1

Propiedades Químicas y Físicas de los Materiales utilizados

(Chemical and Physical Properties of the Raw Materials)

\begin{tabular}{|c|c|c|c|c|c|c|c|c|c|c|c||}
\hline $\begin{array}{c}\text { Sample } \\
\text { Muestra }\end{array}$ & $\begin{array}{c}\text { I. L. } \\
\%\end{array}$ & $\begin{array}{c}\mathrm{I} . \mathrm{R} . \\
\%\end{array}$ & $\begin{array}{c}\mathrm{SiO}_{2} \\
\%\end{array}$ & $\begin{array}{c}\mathrm{Fe}_{2} \mathrm{O}_{3} \\
\%\end{array}$ & $\begin{array}{c}\mathrm{Al}_{2} \mathrm{O}_{3} \\
\%\end{array}$ & $\begin{array}{c}\mathrm{CaO} \\
\%\end{array}$ & $\begin{array}{c}\mathrm{MgO} \\
\%\end{array}$ & $\begin{array}{c}\mathrm{SO}_{3} \\
\%\end{array}$ & $\begin{array}{c}\mathrm{Na}_{2} \mathrm{O} \\
+ \\
\mathrm{K}_{2} \mathrm{O}\end{array}$ & $\begin{array}{c}\mathrm{S} . \mathrm{G}_{2} \\
\mathrm{~kg} / \mathrm{m}^{3}\end{array}$ & $\begin{array}{c}\mathrm{B}_{2} \mathrm{~F} \\
\mathrm{~m}^{2} / \mathrm{kg}\end{array}$ \\
\hline $\mathrm{OPCl}$ & 2.51 & 0.96 & 20.11 & 1.75 & 6.66 & 62.40 & 1.27 & 3.72 & 1.40 & 3080 & 320 \\
\hline $\mathrm{OPC} 2$ & 2.56 & 0.46 & 22.30 & 4.94 & 1.74 & 64.29 & 0.25 & 2.31 & 0.60 & 3210 & 327 \\
\hline $\mathrm{MK}$ & 0.40 & - & 57.48 & 0.50 & 41.55 & 0.01 & 0.00 & 0.00 & 0.04 & 2520 & 333 \\
\hline
\end{tabular}

La Figura 1 presenta una micrografia del metacaolín. El diagrama de difracción de Rayos X, presentado en la Figura 2, corrobora sus características amorfas. La única sustancia cristalina detectada en pequeña cantidad, corresponde a cuarzo. La actividad puzolánica de este material fue evaluada por dos técnicas: el método químico o ensayo de Frattini y el método ASTM C311. En los dos casos los valores que se han obtenido demostraron su carácter puzolánico. La norma ASTM C618 especifica un índice de actividad mínimo para una puzolana del $75 \%$, el metacaolín aporto un valor de $77,2 \%$. En términos generales, $\mathrm{MK}$ cumple las características para ser clasificada, de acuerdo a esta mísma norma, como puzolana tipo $\mathrm{N}$.

Para evaluar la resistencia a la compresión y la durabilidad (contra el ataque de cloruros) se prepararon morteros de cementos portland adicionados con MK en porcentajes en peso hasta del $50 \%$. Para medir el desarrollo mecánico- resistente, se utilizaron moldes cúbicos de 50,8 mm de lado y se siguieron los procedimientos recomendados en la norma ASTM C109. Las probetas se desmoldaron a las 24 horas y se curaron bajo agua hasta la edad de 28 días.
Figure 1 presents a micrograph of the MK. Its XRD pattern shown in Figure 2 indicates a high amorphous character. The only present crystalline phase is a small proportion of quartz. The pozzolanic activity of MK was proved by two different methods: chemical method or Frattini Test and ASTM C311. In both cases, the values obtained demonstrate that the $M K$ is a high reactive pozzolan. ASTM C618 specifies a minimum pozzolanic activity Index of $75 \%$; in this study an Index of $77.2 \%$ was obtained. In general, $M K$ fits the ASTM C618 class $N$ pozzolan specifications.

Portland cement mortars blended with $M K$ additions up to $50 \%$ by weight were prepared. The compressive strength and several durability properties were tested. $50.8 \mathrm{~mm}$ cubes were used to measure the compressive strength development. The proportions of the mix were in accordance with ASTM C109. The specimens were demoulded after 24 hours and cured underwater for 28 days. 


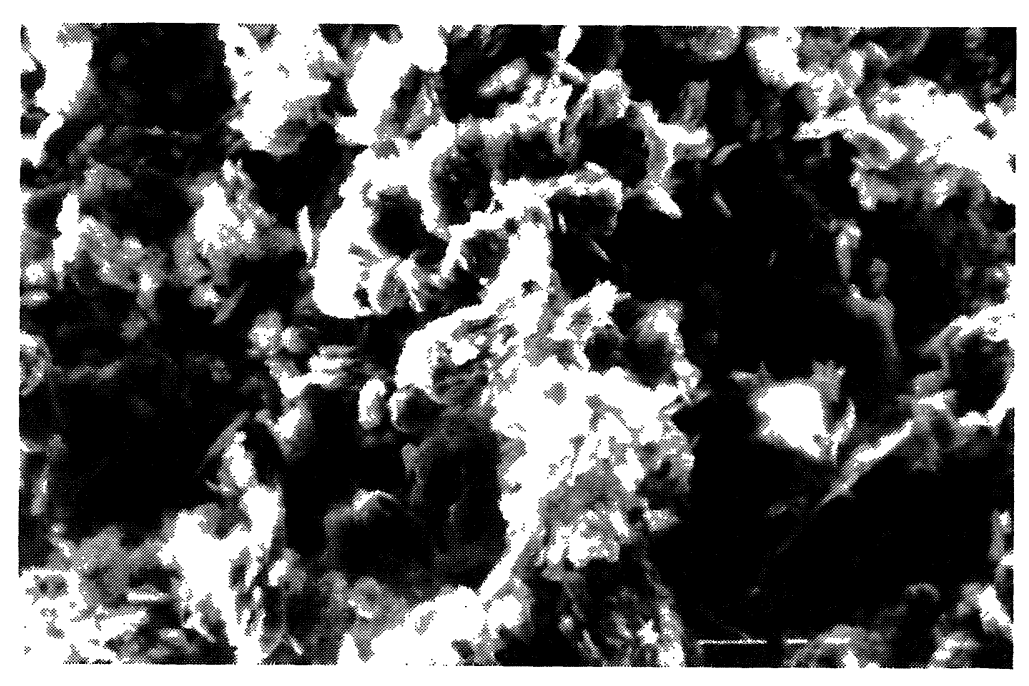

Figura 1.- Micrografia de MK (SEM).

Figure 1.- MK Micrograph (SEM).

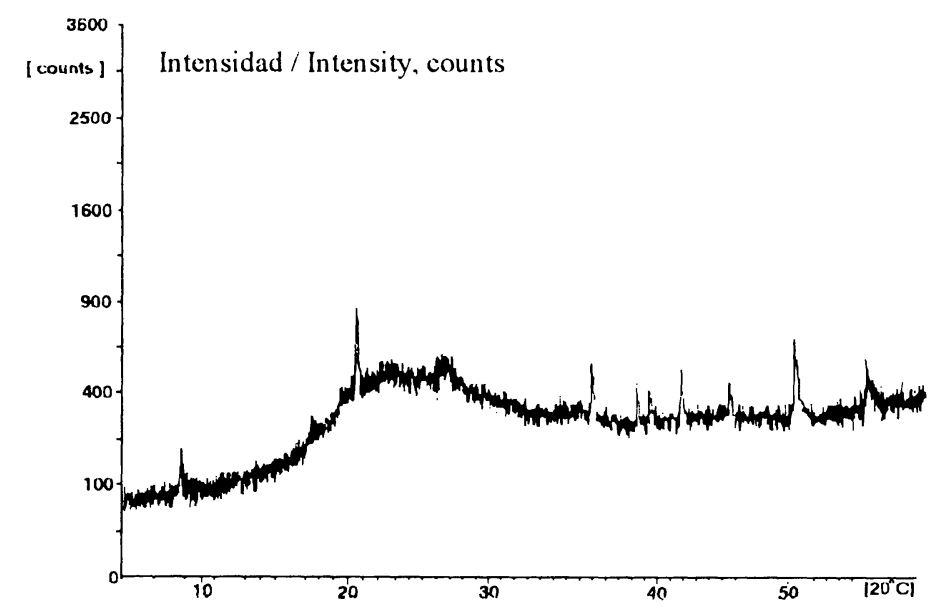

Figura 2.- Patrón de Difracción de Rayos X para el MK.

Figure 2.- XRD Pattern of $M K$

\section{RESULTADOS Y DISCUSIÓN}

\subsection{Resistencia a la compresión}

La Figura 3 presenta un gráfico del índice de actividad resistente en función del contenido de MK en la mezcla. Este índice se calculó como la relación entre la resistencia del mortero adicionado con MK y la resistencia del mortero sin adición, para la edad de 28 días de curado. La resistencia a la compresión de las mezclas con MK fue significativamente superior a las obtenidas con la mezcla de control. Morteros adicionados con el $20 \%$ de MK proporcionaron un incremento de la resistencia mecánica de hasta un $22 \%$. Otros investigadores han confirmado resultados similares (15).

\section{RESULTS AND DISCUSSION}

\subsection{Compressive strength}

Figure 3 presents a plot of the strength index versus the MK contents. The index is the ratio of the strength of the MK mortar to the strength of the control mortar after 28 days of curing. The compressive strength of the MK mixtures was significantly greater than that of the control mixture. The mechanical strength increased up to a maximum of $22 \%$ at $20 \%$ of $M K$ addition. Others researchers have obtained similar results when $M K$ replacement of $O P C$ in concrete has been done (15). 


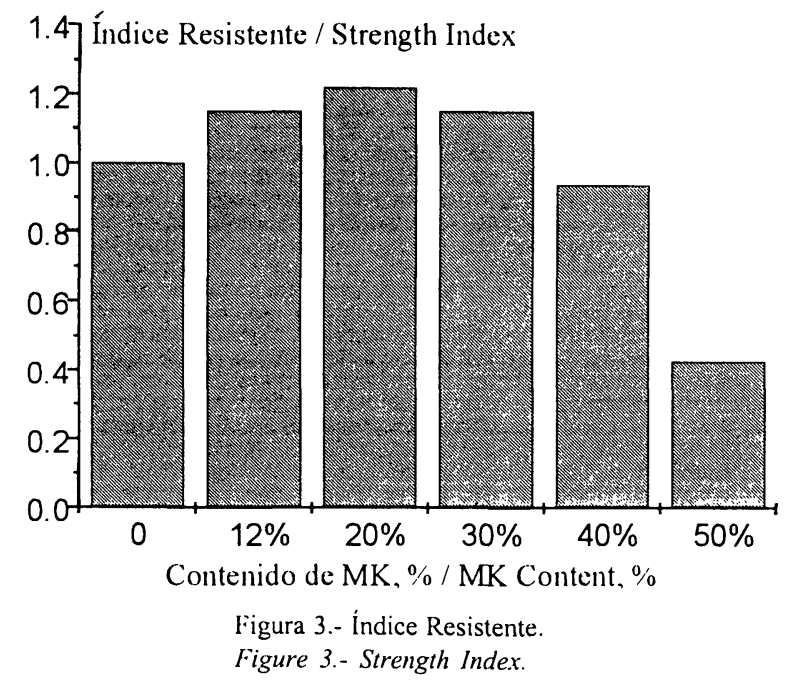

\subsection{Distribución del tamaño de poros y penetración de cloruros}

Para determinar la porosidad y la distribución del tamaño de poros de las diferentes mezclas se utilizó la técnica de porosimetria de mercurio. La Tabla 2 presenta el tamaño de poro promedio para los morteros con y sin adición de MK. Estos resultados corresponden a las probetas curadas a un año. Hay una disminución significativa en el tamaño promedio de poro a medida que se incrementa el contenido de MK en la mezcla. El efecto de la adición de MK en la distribución de los poros se puede observar en la Tabla 3. Los resultados muestran que en presencia de la adición de MK se obtiene una

\subsection{Pore size distribution and chloride penetration}

Mercury intrusion porosimetry was used to determine porosity and pore size distribution. Table 2 presents the average pore diameter for mortars with and without MK at different contents. These results correspond to testing of specimens cured for one year. There is a significant decrease in average pore size with an increase in $M K$ replacement. The effect of $M K$ on the pore size distribution of mortars can be observed in Table 3. The results show that a finer pore structure is obtained with MK addition. The

TABLA 2 / TABLE 2

Diámetro Promedio de Poros en Morteros Adicionados (Average Pore Diameter in Blended Mortars)

\begin{tabular}{|c|c|c|c|c|}
\hline $\mathbf{M K}, \%$ & 0 & 12 & 20 & 40 \\
\hline$\mu \mathbf{m}$ & 0.0543 & 0.0477 & 0.0339 & 0.0328 \\
\hline
\end{tabular}

TABLA 3 / TABLE 3

Efecto de la Adición de MK en la Distribución de Poros (Effect of MK Addition in the Pore Distribution)

\begin{tabular}{|c|c|c||}
\hline \hline $\begin{array}{c}\text { Diámetro de poros } \\
\text { (Pore diameter, } \\
\mu \mathrm{m})\end{array}$ & \multicolumn{2}{|c|}{$\begin{array}{c}\text { Contenido de MK, \% } \\
\text { (MK content, \%) }\end{array}$} \\
\cline { 2 - 3 } & 0 & 40 \\
\hline$>1$ & $6.6 \%$ & $2.9 \%$ \\
\hline $1-0.1$ & $40.8 \%$ & $30.6 \%$ \\
\hline $0.1-0.01$ & $47.2 \%$ & $60.5 \%$ \\
\hline $0.01-0.001$ & $5.4 \%$ & $6.0 \%$ \\
\hline
\end{tabular}


estructura de poros más fina, un $66,5 \%$ de los poros presentan tamaño inferior a $0,1 \mu \mathrm{m}$. Lo anterior confirma lo dicho por otros investigadores (16). Massazza (1) explica la aparente contradicción entre una mayor porosidad total y una baja permeabilidad en mezclas puzolánicas, en términos de que, aunque los productos formados en la reacción puzolánica no están en capacidad de rellenar los poros mayores, sí obstruyen los canales existentes entre los poros, a consecuencia de lo cual la permeabilidad se reduce.

Los resultados de los ensayos de penetración de cloruros (Norma ASTM C1202) para las diferentes mezclas se aprecian en la Figura 4. La carga relativa pasada a través de la probeta de ensayo se expresó como $\left(\mathrm{Q}_{\mathrm{MK}} / \mathrm{Q}_{\text {control }}\right) \times 100$, donde $\mathrm{Q}_{\mathrm{MK}}$ representa la carga pasada a través de la probeta adicionada con $\mathrm{MK}$. En esta figura se presentan simultáneamente los resultados del ensayo de penetración de agua (incremento de la resistencia a la penetración de agua, RWP) para los mismos morteros. El coeficiente de difusión medido en una celda de difusión fue de 2,7 $\times 10^{-13} \mathrm{~m}^{2} / \mathrm{s}$, para los morteros adicionados con un $40 \%$ de $\mathrm{MK}$, y de $1,9 \times 10^{-12} \mathrm{~m}^{2} / \mathrm{s}$, para el cemento portland sin adición (mezcla de control). Como se observa, MK reduce la cantidad de agua absorbida así como la velocidad de penetración de los iones cloruro, lo cual está en concordancia con lo expresado por diferentes investigadores (10) (17).

El contenido elevado de aluminio en el metacaolín, el cual es capaz de enlazar los iones cloruro para producir la sal de Friedel (SF), puede considerarse como la causa fundamental de la menor penetración de los cloruros en los morteros adicionados de cemento portland con MK. La capacidad de enlace químico con los cloruros fue corroborada mediante difracción de rayos X, tal como se puede apreciar en la Figura 5. En este ensayo el cemento OPC corresponde (Tabla 1) a aquél que tiene un bajo contenido en alúmina $\mathrm{y}$, por

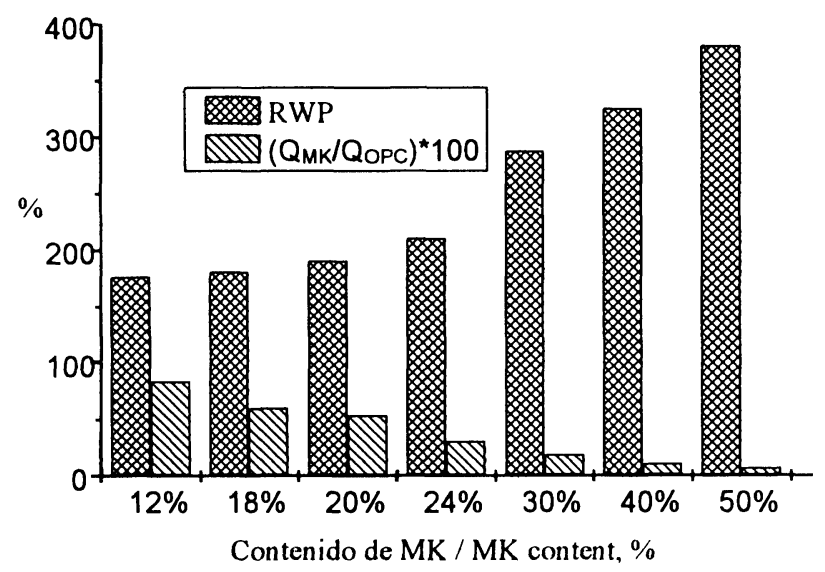

Figura 4.- Resistencia a la Penetración de Agua y a la Permeabilidad de Cloruros.

Figure 4.- Resistance to Water Penetration and Chloride Permeability. portion of pores with diameter lower than $0.1 \mu \mathrm{m}$ was $66.5 \%$. This is in accordance with other researcher (16). Massazza (1) explained the apparent contradiction between the higher porosity and the lower permeability of pozzolanic cements in terms of a model where the small volume of the precipitating products is unable to fill the larger pores but it is sufficient to obstruct the thin connections existing between these pores. As a consequence the porosity could be higher although the permeability is reduced.

The testing results of samples with different $M K$ contents under the chloride penetration procedure (ASTM C1202) are shown in Figure 4. The relative charge passed through the test specimen is expressed as $\left(Q_{M K} / Q_{\text {contro }}\right) x 100$, where $Q_{M K}$ represented the charge of the $M K$ blended mortar. In the mentioned Figure 4 the results of the resistance to water penetration (RWP) for the same type of mortars are presented. The diffusion coefficient measured in a diffusion cell reported $2.7 \times 10^{-13} \mathrm{~m}^{2} / \mathrm{s}$ for the $40 \% \mathrm{MK}$ blended mortars and $1.9 \times 10^{-12} \mathrm{~m}^{2} / \mathrm{s}$ for the cement portland mortar without addition (control mixture). Therefore, $M K$ reduces the quantity of water absorbed and the rate of diffusion of chloride ions (10) (17).

The high aluminum content in the metakaolinite, which is able to bind chloride ions and produce Friedel's salt (SF), can be considered as the main cause of the lower chloride penetration in portland cement mortars blended with MK additions. The chemical binding capacity was proved by XRD, as shown in Figure 5. In this figure the cement used was OPC2 (Table 1), which has a very low alumina percent and calcium chloroaluminate (FS) is not observed in its XRD. On the contrary, the mortar with

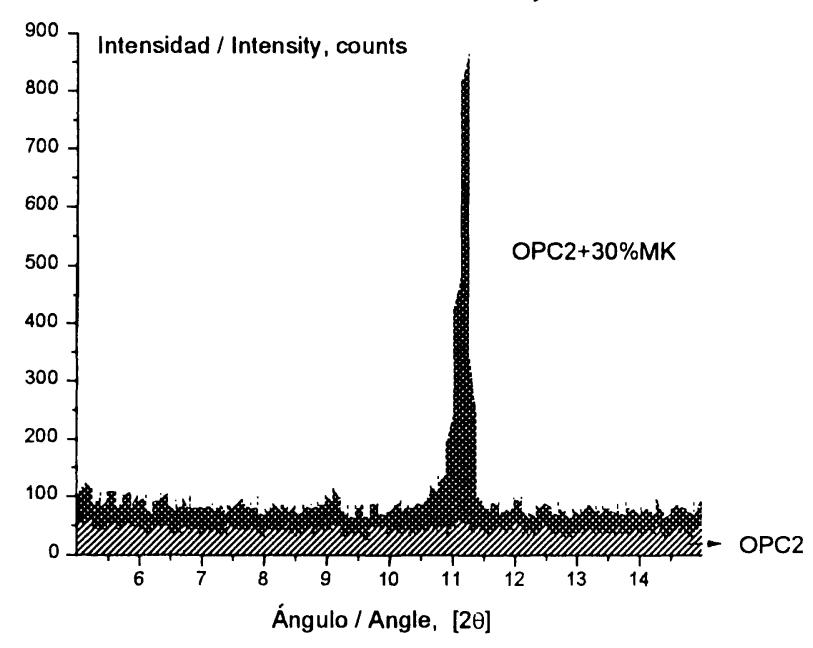

Figura 5.- Patrón de Rayos X (Sal de Friedel). Figure 5.- XRD Pattern (Friedel's Salt). 
tanto, no forma el cloroaluminato de calcio (SF). Por el contrario, en presencia del $30 \%$ de MK se aprecia la formación de la sal de Friedel en apreciables cantidades. Otra causa de la resistencia a la penetración de cloruros de los morteros adicionados con $\mathrm{MK}$, es la modificación del tamaño y distribución de la red de poros del sistema. Este último efecto es a consecuencia de la excelente y peculiar actividad puzolánica del material.

Coleman y Page (18) evaluaron la cantidad de cloruros libres en la disolución de los poros de pastas de cemento adicionado con MK en proporciones del 10 y $20 \%$, expuestas a diferentes niveles de cloruros y aportan, igualmente, mayor capacidad de enlace en presencia de metacaolín adicionado en proporciones del 10 y $20 \%$. Estudios de campo realizados en obras construidas en los últimos años incorporando al hormigón un $15 \%$ de metacaolín, y expuestas durante un máximo de tres años a ambientes agresivos, particularmente en presencia de cloruros, han demostrado un excelente desarrollo resistente y una baja permeabilidad a los cloruros (12)

\subsection{Resistencia a la corrosión del acero de refuerzo}

Una mezcla de OPC2 adicionado con el $30 \%$ de MK se utilizó para estudiar la resistencia a la corrosión del acero de refuerzo. Se prepararon probetas cilíndricas de $50,8 \mathrm{~mm}$ de diámetro, con una barra de acero de $12,7 \mathrm{~mm}$ de diámetro, ubicada a nivel central y se colocaron inmersos parcialmente en una disolución de hidróxido de calcio conteniendo $3,5 \%$ de $\mathrm{NaCl}$, registrándose el potencial de media celda (ASTM C876) del acero de refuerzo. Los resultados obtenidos se muestran en la Figura 6. Según la norma un potencial numéricamente mayor que $270 \mathrm{mV}$ (electrodo de referencia de calomel, SCE) es indicativo de un proceso de corrosión. Los resultados presentados en la figura muestran un comportamiento superior para los morteros adicionados respecto al mortero de control, la relación es de 15:1 en términos del tiempo de iniciación del proceso corrosivo.

La resistencia de polarización $\left(R_{p}\right)$ se muestra en la Figura 7. La Resistencia fue superior para las barras reforzadas embebidas en las probetas adicionadas (OPC2+30\%MK), lo que indica claramente una velocidad de corrosión reducida. Estos menores valores de velocidad de corrosión pueden atribuirse al efecto conjunto de una menor velocidad de difusión de cloruros y una mayor capacidad de enlace.
$30 \% M K$ presents a relative high amount of $F S$. The second reason is the reduced permeability of the pore system in mortars containing MK. This last effect is a result of the excellent and peculiar pozzolanic activity.

Coleman and Page (18) studied the effects of replacement additions of $M K$ on the pore solution chloride ion concentrations for samples containing various percentages of internal chloride ions and reported that the blended cement pastes exhibit higher capacities than plain OPC pastes to bind chloride ions (12).

\subsection{Corrosion resistance of steel reinforcement}

OPC2 added with 30\% MK was also used to study the corrosion resistance of steel reinforcement. $50.8 \mathrm{~mm}$ of diameter cylindrical specimens containing a 12.7 $\mathrm{mm}$ bar embedded centrally were made and were subjected to accelerated corrosion tests by partial immersion in a dissolution of $\mathrm{Ca}(\mathrm{OH})_{2}$ with $\mathrm{NaCl}$ $3.5 \%$. The half-cell potential of this reinforcing steel mortar specimens was studied by the ASTM C876 method and the results are presented in Figure 6. Here, a half-cell potential numerically greater than $270 \mathrm{mV}$ indicates that steel corrosion is occurring. These results show that mortars made with $30 \% \mathrm{MK}$ addition perform 15:1 times better than the OPC mortar control in terms of corrosion initiation time.

The polarization resistance $\left(R_{p}\right)$ is plotted in Figure 7 . As shown, $R_{p}$ for reinforcing bars embedded in blended specimens (OPC2+30\%MK) was higher, so the corrosion rate is reduced. This lower corrosion rates of steel in $M K$ blended cements may be attributed to the conjoint effect of a lower diffusion rate of chloride ions and its higher binding capacity. 
Potencial de media celda, $\mathrm{mV}(-\mathrm{SCE})$

Half Cell Potential, $\mathrm{mV}(-\mathrm{SCE})$

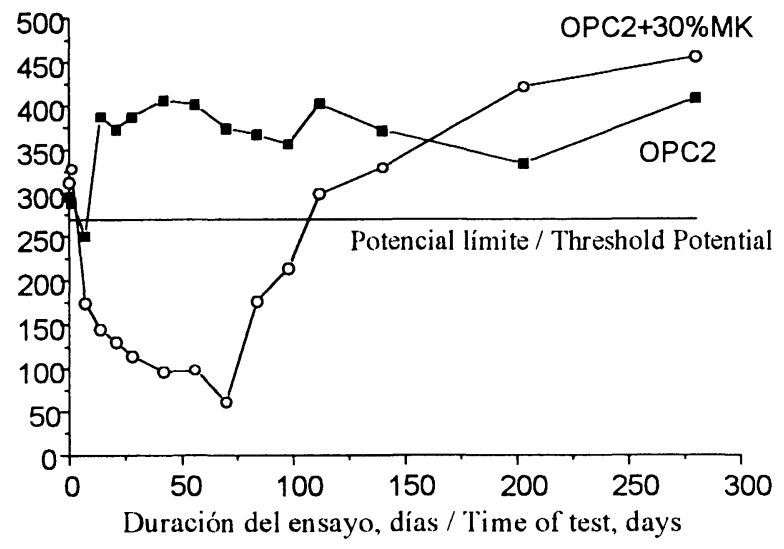

Figura 6.- Potencial de media celda, ASTM C876.

Figure 6.- Half-cell potential measurements, ASTM C876.

\section{CONCLUSIONES}

Los resultados de este estudio indican que MK es una puzolana de alta calidad que presenta muchas ventajas cuando es incorporada en morteros de cementos portland, tales como:

. La adición de MK reduce el tamaño promedio de los poros del mortero y modifica la distribución de éstos en la microestructura del material. Especialmente reduce la porción de poros de diámetro superior a $0,1 \mu \mathrm{m}$.

- La adición de MK incrementa la resistencia y reduce la absorción de agua y la penetración de cloruros.

- El tiempo de iniciación de la corrosión de las barras de acero en mortero adicionado con MK es mayor comparado con el comportamiento del cemento solo y, por tanto, la resistencia a la corrosión es superior.

También ha sido demostrada la formación de la sal de Friedel debida al alto contenido de aluminio del metacaolín. Este compuesto contribuye a la reducción de la permeabilidad a los cloruros en el mortero de cemento portland en virtud del enlace químico con los iones cloruro.

En este sentido, la incorporación de la adición de MK en cementos se recomienda para producir hormigones de elevadas prestaciones, en particular, en medios altamente agresivos tales como el marino y sales de deshielo.

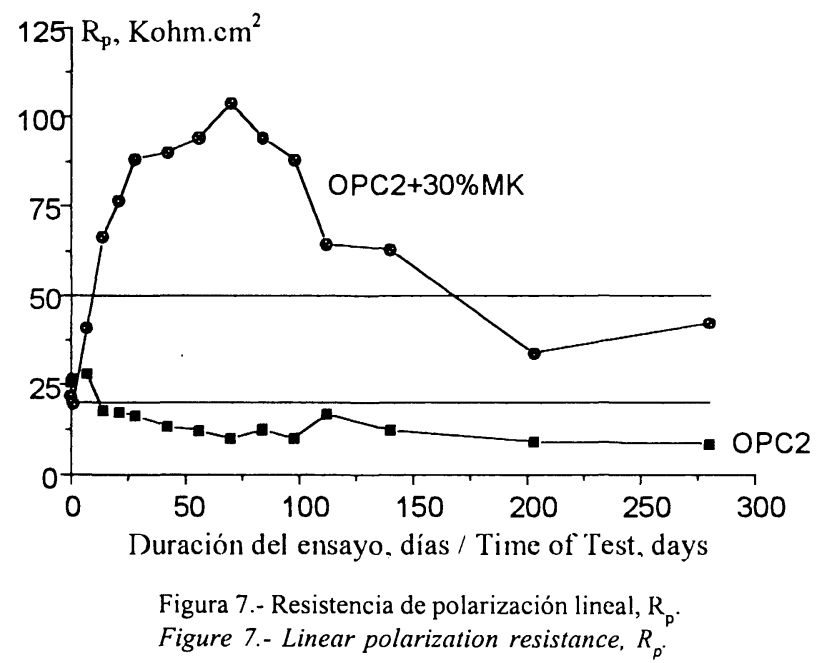

\section{CONCLUSIONS}

The results of this study indicate that MK is a high quality pozzolan that presents many advantages when it is used in mortars, as follows:

. The addition of $M K$ reduces the average pore size of the mortar structure and modifies the pore distribution. Specially, it reduces the portion of pores with diameter higher than $0.1 \mu \mathrm{m}$.

. The addition of $M K$ increases the strength and reduces the water absorption and the chloride penetration.

. The corrosion initiation time of the steel bars in blended mortar is very higher compared to the performance of the cement alone and the corrosion resistance is better as well.

Also, It was demonstrated the generation of Friedel's salt because of the high aluminum content in the metakaolinite. This compound contributes to the reduction of the chloride permeability in a Portland cement mortar due to the bonding of the chloride ions.

In this sense, the incorporation of $M K$ can be recommended as a supplementary cementing material to produce high performance concrete particularly for use in marine environments and thawing salts.

\section{BIBLIOGRAFÍA}

(1) F. Massaza: Pozzolanic Cements, Cement and Concrete Composites, 15 (1993): pp. 185-214.

(2) M. Murat: Hydration Reaction and Hardening of Calcined Clays and Related Minerals. I. Preliminary Investigation of Metakaolinite, Cement and Concrete Research, 13 (1983): pp. 259-266. 
(3) M. Murat: Hydration Reaction and Hardening of Calcined Clays and Related Minerals. II. Influence of Mineralogical Properties of the Raw-Kaolinite on the Reactivity of Metakaolinite, Cement and Concrete Research, 13 (1983): pp. 511-518.

(4) M. Murat, C. Comel: Hydration Reaction and Hardening of Calcined Clays and Related Minerals. III. Influence of Calcination Process of Kaolinite on Mechanical Strengths of Hardened Metakaolinite, Cement and Concrete Research, 13 (1983): pp. 631-637. (5) J. Sanz et al.: Aluminum-27 and Silicon-29 Magic-Angle Spinning Nuclear Magnetic Resonance Study of the Kaolinite-Mullite Transformation, J. Am. Ceram. Soc., 71(10) (1988): pp. C148-C421.

(6) A. Balogh: High-reactivity Metakaolin, Concrete Construction, 40 (1995).

(7) T. Kuennen: Metakaolin might, Concrete Products (1996).

(8) D. Marsh: An Alternative to Silica Fume?, Concrete Products (1994).

(9) J. A. Kostuch, V. Walters, T. R. Jones: High Performance Concretes Incorporating Metakaolin: A Review, Concrete 2000, (1993): pp. 1799-1811.

(10) M. Calderone, K. A. Gruber, R. Burg: High-Reactivity Metakaolin: A New Generation Mineral Admixture, Concrete International, november(1994): pp. 37-40

(11) G.V. Walters, T. R. Jones: Effect of Metakaolin on Alkali-silica Reaction (ASR) in Concrete Manufactured with Reactive Aggregate, Procc. $2^{\text {nd }}$ Int. Conf. On Durability of Concrete, Montreal (1991): pp. 941-953.

(12) A.H. Asbridge, T. R. Jones, G. J. Osborne: High Performance Metakaolin Concrete: Results of Large Scale Trials in Aggresive Environments, Radical concrete Technology, R.K. Dhir and P.C. Hewlett ed., London (1996): pp. 13-24.

(13) J. M. Khatib, S. Wild, Sulphate Resistance of Metakaolin Mortar, Cement and Concrete Research, 28 (1998): pp. 83-92

(14) R. M. de Gutiérrez, R. Talero: A High Reactive Aluminosilicate Pozzolan, IV International Conference on Advanced MaterialsSymposium\#8 Advanced Cement Materials (Méjicu, 1995).

(15) S. Wild, J. M. Khatib, A. Jones: Relative Strength, Pozzolanic Activity and Cement Hydration in Superplasticised Metakaolin Concrete, Cement and Concrete Research, 26 (1996): pp. 1537-1544.

(16) J. M. Khatib, S. Wild: Pore Size Distribution of Metakaolin Paste, Cement and Concrete Research, 26 (1996): pp. 1545-1553

(17) J. G. Cabrera, S. O. Nwaubani: Strength and Chloride permeability of Concrete Containing Red Tropical Soils, Magazine of Concrete Research, 45 N$^{\circ} 164$ (1993): pp. 169-178.

(18) N. J. Coleman, C. L. Page: Aspects of the Pore Solution Chemistry of Hydrated Cement Pastes containing Metakaolin, Cement and Concrete Research, 27 (1997): pp. 147-154. 